\section{Evaluation of Flower Bud Removal Treatments on Growth of Young Blueberry Plants}

\author{
Jeffrey G. Williamson ${ }^{1}$ \\ Horticultural Sciences Department, University of Florida, P.O. Box 110690 , \\ Gainesville FL 32611-0690

\section{Scott NeSmith GA 30223} \\ Department of Horticulture, University of Georgia Griffin Campus, Griffin,
}

Additional index words. Vaccinium corymbosum, Vaccinium ashei, rabbiteye blueberry, southern highbush blueberry, plant establishment, hydrogen cyanamide

\begin{abstract}
The effects of flower bud removal treatments on growth of young rabbiteye (Vaccinium ashei Reade) and southern highbush ( $V$. corymbosum hybrids) blueberry plants were evaluated. Treatments consisted of pruning, hand stripping, and hydrogen cyanamide applications. The growth index of rabbiteye plants after the first spring growth cycle was unaffected by any of the flower bud removal treatments. However, the effects of flower bud thinning were cultivar specific for southern highbush blueberry plants. 'Misty' plants showed increases in total plant dry weight and in root, leaf, and stem dry weights from hand thinning and hydrogen cyanamide sprays. Conversely, 'Santa $\mathrm{Fe}$ ' showed no increased growth response from any of the flower bud removal treatments. Flower bud mortality increased as hydrogen cyanamide spray concentration increased and was greater when applications were delayed so that flower buds were more advanced. Hydrogen cyanamide may have potential as an alternative to labor-intense flower bud removal practices such as hand stripping or pruning on young blueberry plants during establishment.
\end{abstract}

Blueberry acreage in the southeast United States has increased significantly during the last 5 years and continued expansion is expected for the foreseeable future (National Agricultural Statistics Service, 2007; Scherm et al., 2001; Williamson and Lyrene, 2004). This projected increase in acreage suggests that many growers will be planting new orchards with the goal of rapid, uniform plant establishment. One concern with the establishment of blueberry plantings is fruit set and development on young plants. Flower buds are typically removed from blueberry plants during the first year after planting (Pritts, 2006; Williamson et al., 2004; Yarborough, 2006). Current recommendations in many states call for hand removal of flowers or fruit of blueberry plants for the first one or two growing seasons after planting. This procedure is usually accomplished either by walking through the orchard and hand stripping flower buds after planting during the spring, or by heading back shoots having flower buds at the time of planting. These labor-intensive operations can be costly for growers during the establishment period when returns from the crop are minimal (Strik and Buller, 2004). The conventional reason given for removing flowers and fruit on young plants is to reduce

Received for publication 10 Jan. 2007. Accepted for publication $26 \mathrm{Feb} .2007$.

${ }^{1}$ To whom reprint requests should be addressed; e-mail jgrw@ufl.edu plant stress that is associated with maintaining a crop load (Eck, 1988; Gough, 1994; Shutak and Marucci, 1966). However, there is limited research data available concerning effects of flower or fruit removal methods on young plants (Strik and Buller, 2004).

Hydrogen cyanamide has been used in blueberry production in the southeast United States to stimulate leaf growth and advance the ripening date of blueberries (Williamson and Lyrene, 2004; Williamson et al., 2001, 2002). During these earlier experiments, observations revealed that poorly timed hydrogen cyanamide applications resulted in significant flower bud mortality, even though leaf growth was readily stimulated. Although such a response is undesirable for bearing blueberry plants, the possibility that flower bud removal could be facilitated in nonbearing blueberries during establishment using hydrogen cyanamide arose. The objectives of this research were to determine the effects of flower bud removal achieved by several methods on growth of young rabbiteye blueberry plants, and to determine the effect of rate and timing of hydrogen cyanamide sprays on flower bud removal and growth of young southern highbush blueberry plants.

\section{Materials and Methods}

Rabbiteye experiment. This research was conducted at the University of Georgia Blueberry Research Farm near Alapaha, Ga. Containerized (3.8 L) 'Brightwell' and 'Cli- max' rabbiteye blueberry plants were planted on raised beds with a spacing of $4.0 \mathrm{~m}$ (between rows) $\times 1.5 \mathrm{~m}$ (within row). The plants were irrigated and received typical care for newly planted blueberries, except for flower bud removal treatments. Four treatments were applied during the first year of establishment: 1) control having no flower bud removal; 2) hand stripping of flower buds after planting; 3 ) radical pruning of plants at planting, leaving two to three main stems cut to a height of 15 to $20 \mathrm{~cm}$; and 4) application of a $1.25 \%$ hydrogen cyanamide $(2.5 \%$ Dormex, Degussa Ag, Trostberg, Germany) spray (applied until runoff) to plants during stage 5 of bloom (Spiers, 1978). Treatments were applied to five-plant plots, and there were four replications of each treatment-cultivar combination arranged in a randomized complete block design.

Data collection consisted of measuring the growth index (GI) for each treatment in the fall of each year (1999-2001). The GI was determined as follows:

$$
\mathrm{GI}=(\mathrm{h} \times \mathrm{w} 1 \times \mathrm{w} 2) / 1000
$$

where, $\mathrm{h}$ is the height of plants (in centimeters), and $w 1$ and $w 2$ are the width of plants (in centimeters) perpendicular and parallel to the row respectively. Growth index measurements were made for the two center plants in each plot for a total of eight plants per treatment. Data were subjected to analysis of variance to determine treatment effects.

Southern highbush experiments. Hydrogen cyanamide sprays were applied during bloom to 1-year-old containerized 'Misty' (Exp. 1), and 'Misty' and 'Santa Fe' (Exp. 2) southern highbush blueberry plants. Hydrogen cyanamide sprays were applied to runoff during early and late stages of flowering at concentrations of $0 \%, 1 \%, 2 \%$, and $3 \%(\mathrm{v} / \mathrm{v})$ in Expt. 1, and at concentrations of $0 \%$, $1 \%$, and $2 \%(\mathrm{v} / \mathrm{v})$ in Expt. 2. A nonionic surfactant $(0.25 \%, \mathrm{v} / \mathrm{v})$ was used for all spray treatments in both experiments. In Expt. 1, a hand-thinned treatment was included that consisted of hand removal of all flower buds at the time of the early spray treatment. Early sprays were applied when $20 \%$ ('Misty', Expt. 1) of flower buds were past stage 2 of flower bud development (Spiers, 1978), or when $60 \%$ ('Misty', Expt. 2) or $45 \%$ ('Santa Fe', Expt. 2) of flower buds were past stage 2. Late sprays were applied when $50 \%$ ('Misty', Expt. 1) of flower buds were past stage 2, or when $80 \%$ ('Misty', Expt. 2) or $75 \%$ ('Santa Fe', Expt. 2) of flower buds were past stage 2 . The incidence of shoot dieback (Expt. 1), lateral vegetative budbreak, and flower bud mortality (Exp. 2) were determined for each treatment during the spring after the treatment application. The number of flowers that developed on new growth (Expt. 1); canopy volume (Expt. 2); and leaf, stem, root, and total dry plant weights were determined at the end of one growing season. Completely random designs with five (Expt. 1) or seven (Expt. 2) singleplant replications were used. Analysis of 
variance and regression analysis were used to determine treatment effects.

\section{Results and Discussion}

Rabbiteye experiment. The effects of different flower bud removal methods on the GI are depicted in Fig. 1. There were no significant differences in responses to treatments between the cultivars, so data were pooled for analysis. The control treatment having flower buds left intact set a considerable fruit load the first year. The fruit load suppressed shoot growth during the spring to a degree, but adequate shoot growth resumed later in the growing season such that the GI was similar for all treatments at the end of the first season. Plants that were pruned or had the flower buds stripped by hand initiated rapid shoot growth during the spring of the first year, but again, by Fall 1999 no differences were observed among treatments. The hydrogen cyanamide application was intended to burn off flower buds without injuring the main stems and emerging shoots of plants. The application was successful, as observations revealed that more than $90 \%$ of the flower buds failed to open and set fruit, and rapid shoot growth was initiated in the spring. Some tips of shoots that were treated with the growth regulator were slightly burned, but this apparently did not cause a residual problem. By late summer, plants of all treatments were considerably uniform in growth. Similarly, the GI was not significantly different among treatments in Fall 2000 and Fall 2001.

Southern highbush. The numbers of lateral vegetative budbreaks per centimeter of shoot length were increased by hydrogen cyanamide

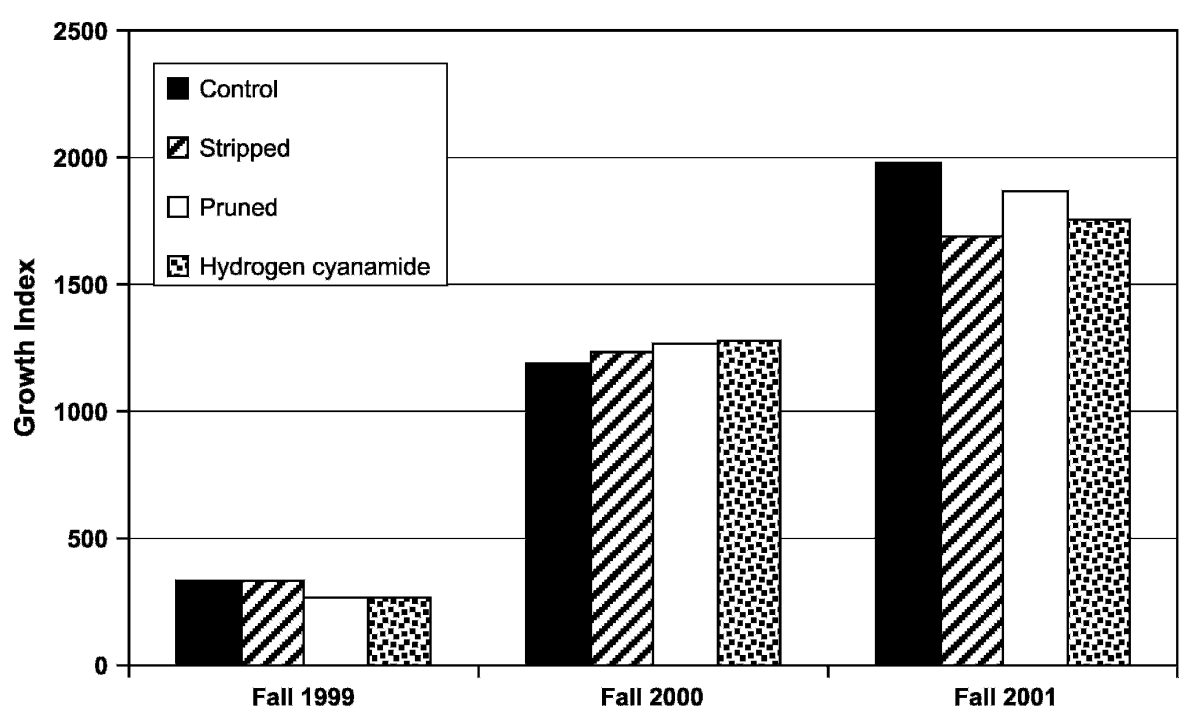

Fig. 1. Growth index of rabbiteye blueberries in response to flower bud removal methods in Alapaha, Ga The control treatment had no flower buds removed, the stripped treatment had flower buds stripped by hand after planting, the pruned treatment received radical pruning of stems at planting, and the hydrogen cyanamide treatment received an application of $1.25 \%$ hydrogen cyanamide at stage 5 of blooming. sprays for both cultivars and in both years (Tables 1-3). This result was expected and is consistent with known responses of southern highbush blueberry to hydrogen cyanamide (Williamson et al., 2001, 2002). In Expt. 1, the number of vegetative budbreaks per centimeter of shoot of 'Misty' increased linearly as treatment concentrations increased. However, in Expt. 2, there was a curvilinear response to rate. In all cases, the number of lateral vegetative budbreaks increased dramatically by hydrogen cyanamide compared with nonsprayed controls or the hand-thinned treatment (Expt. 1). The timing of spray applications relative to flower bud development did not affect lateral vegetative budbreak.

Overall, shoot dieback was greatest for 'Misty' in Expt. 1, although the hydrogen cyanamide rate had no effect on this response variable. Several treatments, including the nontreated control, had more dieback than the hand-thinned treatment. In Expt. 2, shoot dieback increased linearly with increased hydrogen cyanamide concentration for both 'Misty' and 'Santa Fe'. Early versus late sprays had no effect on amount of shoot dieback. Flower bud mortality was only measured in Expt. 2 and it increased linearly with increasing rates of hydrogen cyanamide. The late treatment application resulted in higher flower bud mortality levels than the early treatment for 'Misty' but not for 'Santa Fe'.

Canopy volumes were unaffected by hydrogen cyanamide after one growing season. However, whole plant dry weights, and the dry weights of several plant organs after one growing season, were increased by hydrogen cyanamide treatments for 'Misty' but not for 'Santa Fe' (Tables 2 and 3). In Exp. 1, leaf, stem, and whole plant dry weights were greater for hydrogen cyanamide-treated plants than for controls. The whole plant and organ dry weights of hydrogen cyanamide-treated plants were similar to hand-thinned plants. Similar results were found in Expt. 2 except that root dry weights of the treated plants were about twice that of nonthinned controls. The timing of

Table 1. Expt. 1: Effect of hydrogen cyanamide sprays on growth and development of containerized 'Misty' southern highbush blueberry in Gainesville, Fla.

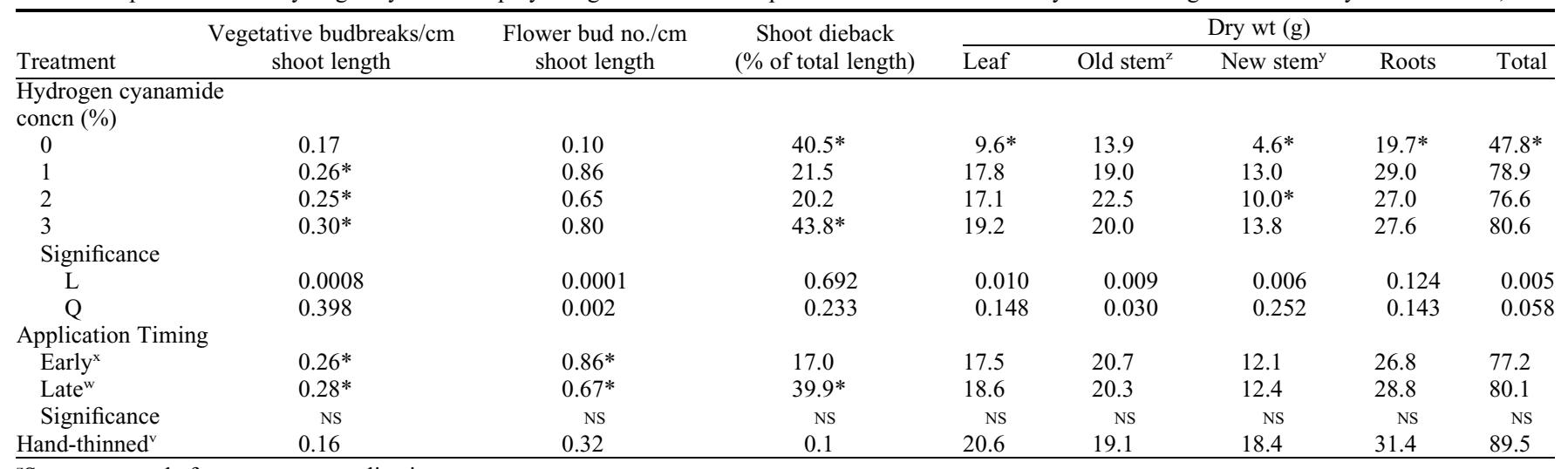

${ }^{\mathrm{z}}$ Stems present before treatment application.

${ }^{\mathrm{y}}$ Stems that grew after treatment application.

${ }^{x}$ Early application applied when $20 \%$ of flower buds were past stage 2 of development.

${ }^{\text {w }}$ Late application applied when $50 \%$ of flower buds were past stage 2 of development.

${ }^{\mathrm{v}}$ All flower buds were removed by hand on $3 \mathrm{Feb}$.

*Differs from hand-thinned treatment $(P \leq 0.05)$. 
Table 2. Expt. 2: Effect of hydrogen cyanamide sprays on flower thinning and growth and development of containerized 'Misty' southern highbush blueberry in Gainesville, Fla

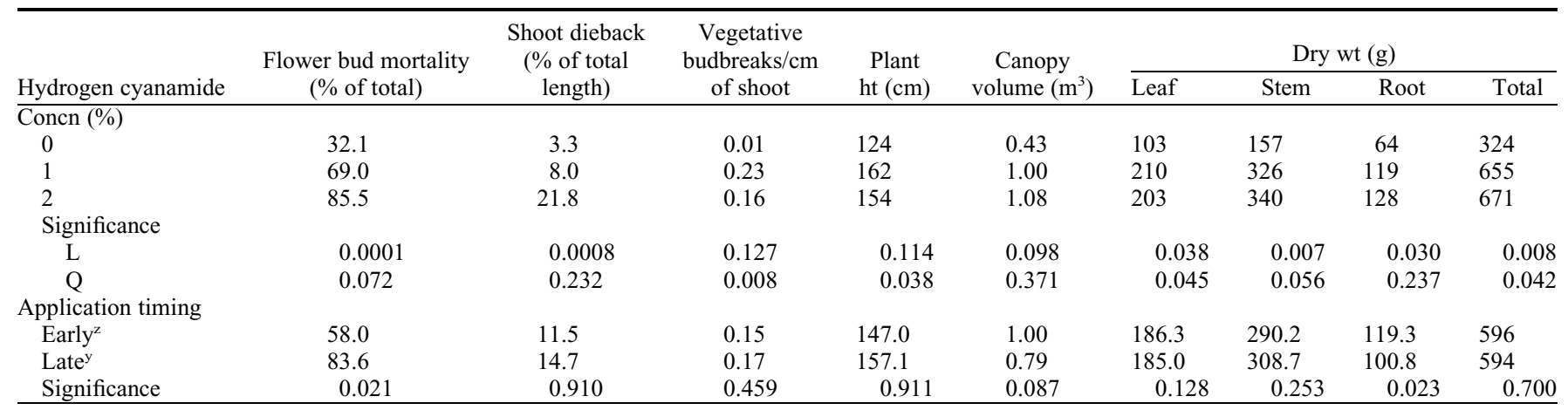

${ }^{\mathrm{z}}$ Early application applied when $50 \%$ of flower buds were past stage 2 of development.

${ }^{y}$ Late application applied when $80 \%$ of flower buds were past stage 2 of development.

Table 3. Expt. 2: Effect of hydrogen cyanamide sprays on flower thinning and growth and development of containerized 'Santa Fe' southern highbush blueberry in Gainesville, Fla.

\begin{tabular}{|c|c|c|c|c|c|c|c|c|c|}
\hline Hydrogen cyanamide & $\begin{array}{c}\text { Flower bud } \\
\text { mortality (\% of total) }\end{array}$ & $\begin{array}{l}\text { Shoot dieback } \\
\text { (\% of total } \\
\text { length) }\end{array}$ & $\begin{array}{l}\text { Vegetative } \\
\text { budbreaks/cm } \\
\text { of shoot }\end{array}$ & $\begin{array}{c}\text { Plant } \\
\text { ht }(\mathrm{cm})\end{array}$ & $\begin{array}{c}\text { Canopy } \\
\text { volume }\left(\mathrm{m}^{3}\right)\end{array}$ & \multicolumn{4}{|c|}{ Dry wt $(\mathrm{g})$} \\
\hline \multicolumn{10}{|l|}{ Concn (\%) } \\
\hline 0 & 2.5 & 0.4 & 0.01 & 2.52 & 156.0 & 289 & 384 & 164 & 837 \\
\hline 2 & 75.6 & 19.4 & 0.14 & 2.07 & 162.5 & 279 & 417 & 178 & 874 \\
\hline \multicolumn{10}{|l|}{ Significance } \\
\hline $\mathrm{L}$ & 0.001 & 0.0001 & 0.004 & 0.213 & 0.396 & 0.814 & 0.281 & 0.820 & 0.603 \\
\hline Earlyz & 59.8 & 14.6 & 0.13 & 2.28 & 157.3 & 273 & 399 & 180 & 851 \\
\hline Late $^{\mathrm{y}}$ & 60.6 & 9.6 & 0.15 & 1.99 & 155.0 & 281 & 419 & 194 & 895 \\
\hline Significance & 0.928 & 0.218 & 0.382 & 0.508 & 0.735 & 0.404 & 0.621 & 0.727 & 0.494 \\
\hline
\end{tabular}

${ }^{\mathrm{z}}$ Early application applied when $45 \%$ of flower buds were past stage 2 of development.

${ }^{y}$ Late application applied when $75 \%$ of flower buds were past stage 2 of development.

hydrogen cyanamide treatments had no effect on plant or organ dry weights except for root dry weights in Expt. 2, in which early sprays resulted in greater root dry weights than later sprays.

Strik and Buller (2004), in a recent study with highbush, indicated removal of flower buds resulted in better growth. In fact, they found that root dry weight was decreased by $42 \%$ as a result of early cropping. They also found that plants allowed to fruit the first year had less flower buds after year 2 than plants that had flower buds removed. However, they indicated that there was a significant and valuable economic yield produced on the early cropped plants, perhaps offsetting the reduced growth.

In the current study with rabbiteye blueberries, yield and flower bud numbers were not measured. The GI, however, did not differ among treatments after the first spring, and observations suggested little residual effect from early cropping. However, the effects of early cropping on the growth of southern highbush blueberry appear to be cultivar specific. Dry weights of many plant organs were greater for 'Misty' plants in which flowers were removed either by hand or by application of hydrogen cyanamide. No effects on plant or organ dry weights were found for 'Santa Fe'. Perhaps cultivars that fruit heavily and lack vigor (such as 'Misty') respond to flower bud removal, whereas cultivars with lighter fruiting tendencies, or with naturally high levels of vigor, do not. Nevertheless, if there are concerns from stressing blueberry plants via early cropping, any of the flower removal treatments used seemed effective. Hydrogen cyanamide appears to have potential as an alternative laborsaving method for removing flower buds in newly established blueberries. However, it should be noted that at present the Dormex label does not support, and even prohibits, use of Dormex for blossom thinning.

\section{Literature Cited}

Eck, P. 1988. Blueberry science. Rutgers University Press, New Brunswick, N.J.

Gough, R.E. 1994. The highbush blueberry and its management. Food Products Press, Binghamton, N.Y.

National Agricultural Statistics Service. United States Department of Agriculture. 2007. Noncitrus fruits and nuts preliminary summary. 3 Jan., 2007. <www.nass.usda.gov>.

Pritts, M.P. 2006. Notes on blueberry pruning, rejuvenation, p. 84-85. In: N.F. Childers and P.M. Lyrene (eds.). Blueberries, for growers, gardeners, promoters. Dr. Norman F. Childers Publications, Gainesville, Fla.

Scherm, H., D.S. NeSmith, D.L. Horton, and G. Krewer. 2001. A survey of horticultural and pest management practices of the Georgia blueberry industry. Small Fruit Rev. 1:17-28.
Shutak, V.G. and P. Marucci. 1966. Plant and fruit development, p. 179-198. In: P. Eck and N.F. Childers (eds.). Blueberry culture. Rutgers University Press, New Brunswick, N.J.

Spiers, J.M. 1978. Effect of bud stage development on cold injury in rabbiteye blueberry. J. Amer. Soc. Hort. Sci. 103:452-455.

Strik, B. and G. Buller. 2004. Effect of in-row spacing and early cropping on yield and dry weight partitioning of three highbush blueberry cultivars the first two years after planting. Small Fruits Rev. 3:141-147.

Williamson, J.G., F.S. Davies, and P.M. Lyrene. 2004. Pruning blueberries in Florida. Fact sheet HS 985. University of Fla. Cooperative Extension Service, Gainesville, Fla.

Williamson, J.G., G. Krewer, B.E. Maust, and E.P. Miller. 2002. Hydrogen cyanamide accelerates vegetative budbreak and shortens fruit development period of blueberry. HortScience 37:539-542.

Williamson, J.G. and P.M. Lyrene. 2004. The Florida blueberry industry: A decade of growth. Proc. Fla. State Hort. Soc. 117:234235.

Williamson, J.G., B.E. Maust, and D.S. NeSmith. 2001. Timing and concentration of hydrogen cyanamide affect blueberry bud development and flower mortality. HortScience 36:922-924.

Yarborough, D.E. 2006. Blueberry pruning and pollination, p. 75-83. In: N.F. Childers and P.M. Lyrene (eds.). Blueberries, for growers, gardeners, promoters. Dr. Norman F. Childers Publications, Gainesville, Fla. 